\title{
10 Insights for Canada - regions in foreign trade
}

Canada is the country for which one of the first documented regional exports analysis was made (DeKaser and Sneddon Little, 1994; Fieleke, 1970; Golladay and Sandoval, 1972; Stabler and Howe, 1988), which was due to data availability. Since then, the literature on Canadian provinces' exports has flourished, and many interesting research threads have evolved, showing the changing nature of the inquiry into the nexus between regional and international issues. Canada has always relied on exports as its major source of income, especially during the era of the expansion of global trade. Before the financial and economic crisis (2008+), Canada witnessed sustained and relatively high economic growth rates. It came as a result of large inflows of foreign capital, which subsequently led to a boom in domestic investment and consumption. However, as in the case of many other economies, the question is asked about the consequences of the growing intensity of trade links of the Canadian provinces with foreign markets, as well as about their changing patterns. Trade is often perceived to create winners and losers; trade can as well enhance or hinder welfare, and lead to regional inequalities. Trade is highly localized. Thus, to deeply understand the dynamics characterising foreign trade relationship, it is crucial not to limit the analyses of trade performance at the national level, but more importantly, to also examine trade at a disaggregated provincial level. Export performance varies significantly across provinces. As a large economy, Canada represents an interesting case study of regional heterogeneity with distinct international trade profiles. The focus of this study is on the Canadian provinces' exports. ${ }^{18}$

Canada represents an interesting case, due to its geographical location, ${ }^{19}$ close to its major trading partner (US), current position as one of the top 10 leading economies

18 Canada is made up of 10 provinces and 3 territories - Western Canada Provinces: (Alberta-AB, Saskatchewan -SK, Manitoba - MB, and British Columbia -BC); Atlantic Provinces: (Newfoundland and Labrador -NFLD\&L, Prince Edward Island -PEI, New Brunswick -NB, and Nova Scotia - NS); Central Canada Provinces: (Ontario -ON and Quebec -QB); Territories: (Northwest Territories - NWT, Yukon, - YKT and Nunavut - NVT). But most studies only consider the provinces, since activities in the territories are mostly considered inconsequential.

19 Canada maintains the world's longest undefended border with the US. In terms of geography $\left(9,985,000 \mathrm{~km}^{2}\right)$, it is the second largest country in the world after Russia (Government of Canada, 2018). Canada has a population of 37 million, with a GDP of CAD2.22 trillion in 2018 (Statistics Canada, 2019a). The big chunk of Canadian population lives in the cities and big metropolitan provinces. The central provinces of Ontario (39\% of the total) and Quebec (23\% of the total) are more populated, other provinces are either moderately or sparsely populated. 
in the world and advances made so far towards quick recovery ${ }^{20}$ from the impact of the global financial crisis.

Canadian exports' characteristic feature is a strong orientation towards its southern neighbour (US) on the one hand, and its sectoral diversification, ${ }^{21 / 22}$ but diversified by products. ${ }^{23}$ Overall, the Canadian economy has gained immensely from export activities in several ways, with an increase in exports linked to higher incomes and living standards (Foreign Affairs and International Trade Canada, 2012). However, the large share of export in the Canadian economy also increases Canada's exposure to external shocks. The response of Canada to changes in the foreign markets has very important policy implications. For example, most trade analysts are of the view that the recent NAFTA renegotiation will impact greatly on Canada, given that more than $75 \%$ of its export activity is destined for NAFTA partners. In the same manner, to mitigate this exposure, Canada would have to pursue a wider export diversification, both at the product and geographical (market) levels.

Generally, the study focuses on the main characteristics of Canadian exports by provinces. First, we provided analysis on the nature of shifts in the frontier of provincial exports, in relation to the influence of border and external relations. Second, we looked at the structure of Canadian exports and provided important facts about the international trade (exports) of the Canadian provinces. Finally, we also presented the relationship between trade (exports) openness and the prosperity of the province, by analysing the correlation between exports per capita and GDP per capita. In the same manner, we also analysed the provincial labour market as it relates to trade openness.

The remainder of the paper is structured as follows: section 10.1 presents the main, selected publications on the Canadian foreign trade. Section 10.2 and 10.3 present a brief analysis of the dynamics in exports, at country and provincial levels. Section 10.4 and 10.5 identifies the nature of co-movement in the export dynamics

20 The quick recovery can be attributed to sound pre-crisis fiscal policy, a solid financial system, a relatively robust external sector and the economic strength of its resource-rich western provinces.

21 Canada's top 10 export sectors in 2018 are: mineral fuels including oil: USD99.3 billion (22\% of total exports); vehicles: USD60.5 billion (13.4\%); machinery including computers: USD34.5 billion (7.7\%); gems, precious metals: USD18.3 billion (4.1\%); wood: USD14.3 billion (3.2\%); plastics, plastic articles: USD13.6 billion (3\%); electrical machinery, equipment: USD13.4 billion (3\%); aircraft, spacecraft: USD10.6 billion (2.4\%); aluminium: USD10 billion (2.2\%); paper, paper items: USD8 billion $(1.8 \%)$.

22 The concentration of Canadian exports to the US is in line with what economic theory predicts. The gravity model of trade tells us that economic size and geographic proximity are the most important determinants of bilateral trade patterns.

23 The exports diversification by product may not have been the ex-ante expectation since Canada is known for its energy and automobile exports. The Canadian product concentration ratio (HHI score) is 0.09 in 2018. This concentration ratio has changed little over the past 28 years, hovering around 0.07 and 0.12 since 1990 , but always remaining under the 0.15 benchmark. 
(exports per capita versus GDP per capita) by provinces. The final section gives a brief conclusion on some interesting peculiarities of the Canadian provinces' exports, the reorientation of some provinces towards the foreign markets and their weakening links with the other Canadian provinces, and a few policy implications regarding the influence of globalisation on provincial economies.

\subsection{Review of Literature}

The review of the literature on the Canadian provinces' exports shows that the research was predominantly focused on the border effect problem; however, also other problems were the subject of research (consequences for welfare, resource course, fluctuating global oil prices). Recent research has moved from the simple exploration of border effects and trade policies to the examination of the likely resultant variation in the provincial export dynamics. A handful of previous studies has been summarised in Table 10.1.

Table 10.1: Literature review on the border effect and external relations for the Canadian provinces

\begin{tabular}{|c|c|c|c|c|}
\hline Author(s) & Topic Addressed & Data & Methodology & Main results \\
\hline $\begin{array}{l}\text { McCallum } \\
\text { (1995) }\end{array}$ & $\begin{array}{l}\text { National borders } \\
\text { matter: Canada- } \\
\text { US regional trade } \\
\text { patterns }\end{array}$ & $\begin{array}{l}\text { Cross- } \\
\text { sectional, } \\
1988\end{array}$ & Gravity model & $\begin{array}{l}\text { Trade between the two Cana- } \\
\text { dian provinces was } 22 \text { times } \\
\text { larger than trade between a } \\
\text { Canadian province and a US } \\
\text { state. }\end{array}$ \\
\hline $\begin{array}{l}\text { Helliwell } \\
(2000)\end{array}$ & $\begin{array}{l}\text { How much do } \\
\text { national borders } \\
\text { matter? }\end{array}$ & $\begin{array}{l}\text { Panel, } \\
\text { 1990-96 }\end{array}$ & Gravity model & $\begin{array}{l}\text { Showed that Quebec trades } \\
\text { more than } 20 \text { times as much } \\
\text { with other provinces than } \\
\text { it does with U.S states of } \\
\text { comparable size and dis- } \\
\text { tance. Border effect dropped } \\
\text { between } 1990 \text { and } 1996 \text { due } \\
\text { to ratification in Canada-US } \\
\text { FTA in } 1988 \text { and improvement } \\
\text { in the gravity model. }\end{array}$ \\
\hline $\begin{array}{l}\text { Anderson } \\
\text { and van } \\
\text { Wincoop } \\
(2003)\end{array}$ & $\begin{array}{l}\text { Gravity with gravi- } \\
\text { tas: A solution to } \\
\text { the border puzzle }\end{array}$ & $\begin{array}{l}\text { Cross } \\
\text {-sectional, } \\
1993\end{array}$ & Gravity model & $\begin{array}{l}\text { National borders reduce } \\
\text { trade between the US and } \\
\text { Canada by about } 40 \% \text {, while } \\
\text { reducing trade among other } \\
\text { industrialized countries by } \\
\text { about } 30 \% \text {. }\end{array}$ \\
\hline
\end{tabular}


Table 10.1: Literature review on the border effect and external relations for the Canadian provinces

\begin{tabular}{|c|c|c|c|c|}
\hline Author(s) & Topic Addressed & Data & Methodology & Main results \\
\hline $\begin{array}{l}\text { Hillberry } \\
\text { (1998) }\end{array}$ & $\begin{array}{l}\text { The national } \\
\text { border effect in US } \\
\text { commodity flow } \\
\text { data }\end{array}$ & $\begin{array}{l}\text { Panel, } \\
1994\end{array}$ & Gravity model & $\begin{array}{l}\text { Showed that the border effect } \\
\text { between } 1990 \text { and } 1996 \\
\text { declined from } 19.5 \text { to } 11.9 . \\
\text { The paper attributes the } \\
\text { decrease to the Canada-US } \\
\text { Free Trade Agreement. }\end{array}$ \\
\hline $\begin{array}{l}\text { Helliwell, } \\
\text { Lee, and } \\
\text { Messinger } \\
\text { (1999) }\end{array}$ & $\begin{array}{l}\text { Effects of the } \\
\text { Canada-US FTA } \\
\text { on interprovincial } \\
\text { trade }\end{array}$ & $\begin{array}{l}\text { Panel, } \\
1988 \text {-96 }\end{array}$ & Gravity model & $\begin{array}{l}\text { First, the results show } \\
\text { clearly that the FTA increased } \\
\text { province-state trade relative } \\
\text { to interprovincial trade. The } \\
\text { second results suggest that } \\
\text { the FTA-related reductions } \\
\text { in Canadian tariffs led to } \\
\text { increases in imports from } \\
\text { the US and to reductions in } \\
\text { interprovincial trade. }\end{array}$ \\
\hline $\begin{array}{l}\text { Knox } \\
(2001)\end{array}$ & $\begin{array}{l}\text { Canada's agree- } \\
\text { ment on (AIT) } \\
\text { internal trade: } \\
\text { it can work if we } \\
\text { want it to }\end{array}$ & $\begin{array}{l}\text { Exten- } \\
\text { sive data } \\
\text { analysis on } \\
\text { Canadian } \\
\text { trade } \\
\text { policy }\end{array}$ & $\begin{array}{l}\text { Descriptive/ } \\
\text { analytical } \\
\text { research }\end{array}$ & $\begin{array}{l}\text { Author claimed no real } \\
\text { effectiveness of the AIT and } \\
\text { argued that AIT failed on } \\
\text { many fronts leaving many } \\
\text { interprovincial barriers still } \\
\text { in place. }\end{array}$ \\
\hline $\begin{array}{l}\text { Coulombe } \\
\text { (2003) }\end{array}$ & $\begin{array}{l}\text { International } \\
\text { trade, interpro- } \\
\text { vincial trade and } \\
\text { Canadian provin- } \\
\text { cial growth }\end{array}$ & $\begin{array}{l}\text { Trend } \\
\text { analysis: } \\
1981 \text { and } \\
2000\end{array}$ & $\begin{array}{l}\text { L-curve and } \\
\text { conditional } \\
\text { convergence- } \\
\text { growth model }\end{array}$ & $\begin{array}{l}\text { There is an 'L' curve that } \\
\text { characterises the compara- } \\
\text { tive evolution of interprovin- } \\
\text { cial and international trade } \\
\text { shares in GDP between } 1981 \\
\text { and } 2000 .\end{array}$ \\
\hline $\begin{array}{l}\text { Kukucha } \\
\text { (2009) }\end{array}$ & $\begin{array}{l}\text { The provinces and } \\
\text { Canadian foreign } \\
\text { trade policy }\end{array}$ & $\begin{array}{l}\text { Time-series } \\
\text { Data: } 1997 \\
-2006\end{array}$ & $\begin{array}{l}\text { Descriptive/ } \\
\text { analytical } \\
\text { method }\end{array}$ & $\begin{array}{l}\text { The author analysed the role } \\
\text { of provinces in the global } \\
\text { political economy and argued } \\
\text { that states and provinces still } \\
\text { can formulate independent } \\
\text { policy. }\end{array}$ \\
\hline $\begin{array}{l}\text { Obstfeld } \\
\text { and } \\
\text { Rogoff } \\
(2000)\end{array}$ & $\begin{array}{l}\text { The six major } \\
\text { puzzles in interna- } \\
\text { tional macroeco- } \\
\text { nomics. Is there a } \\
\text { common cause? }\end{array}$ & $\begin{array}{l}\text { Periods } \\
\text { consistent } \\
\text { with all the } \\
\text { puzzles } \\
\text { addressed }\end{array}$ & $\begin{array}{l}\text { Constant } \\
\text { elasticity of } \\
\text { substitution } \\
\text { model }\end{array}$ & $\begin{array}{l}\text { Found enough ground to } \\
\text { acknowledge findings of } \\
\text { McCallum on border effect } \\
\text { as one the trade puzzles and } \\
\text { also showed the essential } \\
\text { role of trade costs. }\end{array}$ \\
\hline
\end{tabular}


continued Table 10.1: Literature review on the border effect and external relations for the Canadian provinces

\begin{tabular}{|c|c|c|c|c|}
\hline Author(s) & Topic Addressed & Data & Methodology & Main results \\
\hline $\begin{array}{l}\text { Zestos } \\
\text { and Tao } \\
(2002)\end{array}$ & $\begin{array}{l}\text { Trade and GDP } \\
\text { growth: causal } \\
\text { relations in the US } \\
\text { and Canada }\end{array}$ & $\begin{array}{l}\text { Time-series } \\
\text { data (1948- } \\
1996)\end{array}$ & $\begin{array}{l}\text { Vector error } \\
\text { correction } \\
\text { (VEC) model }\end{array}$ & $\begin{array}{l}\text { Found a bidirectional cau- } \\
\text { sality for Canada from the } \\
\text { foreign sector to GDP, but a } \\
\text { weaker relationship between } \\
\text { the foreign sector and GDP } \\
\text { for the US. The Granger } \\
\text { causality tests suggest } \\
\text { that Canada is a more open } \\
\text { economy than the US and } \\
\text { more trade-dependent. }\end{array}$ \\
\hline $\begin{array}{l}\text { Frankel } \\
\text { and } \\
\text { Romer } \\
\text { (1999) }\end{array}$ & $\begin{array}{l}\text { Does trade cause } \\
\text { growth? }\end{array}$ & $\begin{array}{l}\text { Cross- } \\
\text { sectional, } \\
1985 \text { for } \\
63 \text { coun- } \\
\text { tries }\end{array}$ & Gravity model & $\begin{array}{l}\text { Found that trade appears } \\
\text { to raise income by spurring } \\
\text { the accumulation of physical } \\
\text { and human capital and by } \\
\text { increasing output for given } \\
\text { levels of capital. }\end{array}$ \\
\hline $\begin{array}{l}\text { Gaston } \\
\text { and } \\
\text { Trefler } \\
\text { (1997) }\end{array}$ & $\begin{array}{l}\text { The labour market } \\
\text { consequences of } \\
\text { the Canada-US } \\
\text { free trade agree- } \\
\text { ment }\end{array}$ & $\begin{array}{l}\text { Panel, } \\
\text { 1989-1993 }\end{array}$ & $\begin{array}{l}\text { Descriptive/ } \\
\text { analytical } \\
\text { method }\end{array}$ & $\begin{array}{l}\text { The authors found contrac- } \\
\text { tions in employment across } \\
\text { all industries caused by the } \\
\text { FTA. The authors showed } \\
\text { that FTA was not primarily } \\
\text { responsible for Canadian job } \\
\text { loss, and only account for } \\
\text { about } 15 \% \text { of such losses. } \\
\text { They further found that other } \\
\text { factors (including the quest } \\
\text { to curb inflation) account for } \\
\text { more than } 80 \% \text { of job losses } \\
\text { in Canada. }\end{array}$ \\
\hline $\begin{array}{l}\text { Townsend } \\
(2007)\end{array}$ & $\begin{array}{l}\text { Do tariff reduc- } \\
\text { tions affect the } \\
\text { wages of workers } \\
\text { in protected } \\
\text { industries? }\end{array}$ & $\begin{array}{l}\text { Micro- } \\
\text { data on } \\
\text { individual } \\
\text { workers, } \\
2007\end{array}$ & $\begin{array}{l}\text { Descriptive } \\
\text { statistical } \\
\text { method }\end{array}$ & $\begin{array}{l}\text { The author showed that } \\
\text { relative wages fell in the } \\
\text { industries that faced the } \\
\text { deepest tariff cuts. This effect } \\
\text { was experienced regardless } \\
\text { of whether workers belonged } \\
\text { to a union, suggesting that } \\
\text { CUSFTA reduced the returns } \\
\text { to industry-specific human } \\
\text { capital for those workers in } \\
\text { the most heavily affected } \\
\text { industries. }\end{array}$ \\
\hline
\end{tabular}


continued Table 10.1: Literature review on the border effect and external relations for the Canadian provinces

\begin{tabular}{|c|c|c|c|c|}
\hline Author(s) & Topic Addressed & Data & Methodology & Main results \\
\hline $\begin{array}{l}\text { Beaulieu } \\
(2000)\end{array}$ & $\begin{array}{l}\text { The Canada-US } \\
\text { Free Trade Agree- } \\
\text { ment and Labour } \\
\text { Market Adjust- } \\
\text { ment in Canada }\end{array}$ & $\begin{array}{l}\text { Improve- } \\
\text { ment } \\
\text { covering } \\
\text { the } 1997 \\
\text { empirical } \\
\text { investiga- } \\
\text { tion up } \\
\text { to } 2000 \\
\text { period }\end{array}$ & $\begin{array}{l}\text { Descriptive/ } \\
\text { analytical } \\
\text { method }\end{array}$ & $\begin{array}{l}\text { The author provided evidence } \\
\text { suggesting that the Canada- } \\
\text { US FTA (CUSFTA) had almost } \\
\text { no effect on earnings and had } \\
\text { a small negative effect on } \\
\text { manufacturing employment. } \\
\text { The author further suggested } \\
\text { that a change in trade policy } \\
\text { may affect skilled and less- } \\
\text { skilled workers differently } \\
\text { and claimed that the tariff } \\
\text { reductions lowered employ- } \\
\text { ment predominantly among } \\
\text { less-skilled workers but did } \\
\text { not affect the earnings of } \\
\text { either skilled or less-skilled } \\
\text { workers. }\end{array}$ \\
\hline
\end{tabular}

Source: own elaboration.

The implicit framework of the structural gravity model of trade by Anderson and van Wincoop (2003) was meant to explore the extent of trade diversion between interprovincial trade and province-US states trade, in an attempt to revisit the standard border effect literature of McCallum (1995) on Canada and the US. One of the key anchors of the model is Armington's assumption that goods have a place of origin characteristics. The goods can either be traded intra-nationally or/and internationally. Thus, diverting international trade in favour of the national market is one of the resultant effects of trade barriers. Anderson and van Wincoop (2003) proved the non-similarity in the estimates from the standard McCallum-type border effect. Through the gravity framework, McCallum (1995) studied the effect of barriers to trade on Canada-US regional trade patterns. Particularly for the 1988 period, McCallum proved that trade between two Canadian provinces was 22 times larger than trade between a Canadian province and a US state. This same conclusion was also reached by Helliwell (2000), who observed the existence of huge trade between Quebec and other Canadian provinces than with US states of the same size and distance. Obstfeld and Rogoff (2000) acknowledged and referred to this finding as one of the trade puzzles. As has already been acknowledged, an increase in the structure of Canadian tariff would artificially encourage interprovincial trade and results in trade diversion at the expense of the international channels. A reduction or total removal of the same tariff would lead to an increase in international trade, thereby causing a decrease in interprovincial trade 
channels. The institution of FTA brought notable changes to the patterns of provincial trade in Canada. The agreement between Canada and US was effective from January 1, 1989, to January 1, 1998, the content of FTA eliminated or reduced tariffs and non-tariff trade barriers for both countries (Hillberry, 1998). On January 1, 1994, the agreement was extended to Mexico, with the adoption of the NAFTA as the new name. Following this agreement, trade between Canada and its agreement neighbours have continued to expand. Helliwell et al. (1999) have extensively documented and analysed the fall in the relative importance of interprovincial trade vis-à-vis international trade. Using industry-level data on merchandise trade and tariffs, the authors revealed a possible link between FTA and a relative decrease in interprovincial trade.

Other studies on provincial trade have shown numerous other ways in which external relation and border can influence exports, and how these effects can manifest at different levels, including at the sectoral and specific good levels. It is the anchor point of the analysis, well documented in Kukucha (2009), where it was argued that barriers to trade erected by the government are the sources of sectoral variances through which national borders display its relevance or effect. He finds that government regulations are (in most cases) extreme when it comes to food and textile products when compared to other sectors where such government presence is almost completely absent, such as transportation equipment. Some analysts have also considered the importance of export autonomy characterising provincial trade.

\subsection{Trade policy and the evolution of Canadian exports}

Prior to the shocks of 1980s, the entire world was blessed with a rise in international trade. Even more in 1990, after the demise of the former Soviet Union, and the rise of the emerging economy of China (Coulombe, 2003). This period also witnessed a reduction in international trade barriers. For Canada, the reduction in international barriers was stretched further in 1989, after accenting to FTA with the US. Some interprovincial level trade barriers were also raised, and this resulted in major setbacks to Canada until 1995, following the birth of AIT (Coulombe, 2003). Knox (2001) insisted that the real effectiveness of AIT is still riddled with uncertainty. Thus, the questions often raised are those that ask what role adjacency and trade policy played in shaping Canadian trade patterns? Detailed answers to these questions would require the availability of sectoral data and empirical testing through econometric modelling and analysis. However, such deeper econometric pursuit is beyond the scope of this paper.

In this section, we focused on the empirical analysis of the evolution of exports in relation to liberalisation policy, using the latest available data. The comparative evolution of provincial exports is provided by 1981-2017 annual data on goods and services, which is also useful in identifying some important structural changes that took place in the provincial export patterns. The questions often raised relate to the nature of the economics of export patterns. A handful of these questions are: why was 
the share of intra-national exports declining in the 1980s, and remained constant in the 1990s (a period when the international export share was rising), but fluctuated in 2000s? What role did adjacency and external relations such as the CUSFTA and now NAFTA play in shaping Canadian trade patterns? Clearly, we approached the questions by first unravelling the nature of diversion in the international and interprovincial export patterns, as a result of the gravity forces.

The two measures of openness are captured by the shares of interprovincial and international exports in the overall GDP.

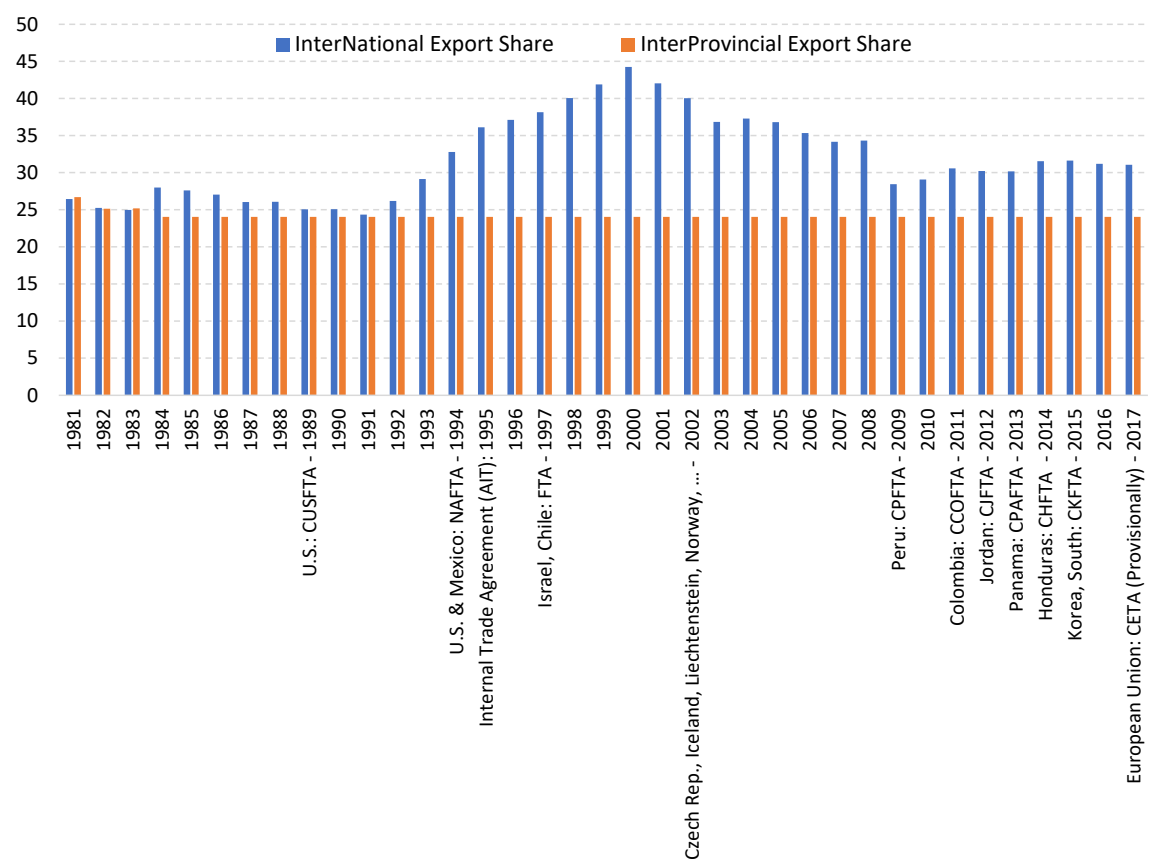

Figure 10.1: Share of international and interprovincial export in GDP. The trend at country level Source: own elaboration (Based on Data from Statics Canada).

Further insights into the nature of trends in export patterns can be shown by disaggregating export total into goods and services components or sectors. In the same manner, as previously, we derive the index of shares in exports for goods and for services at the national level, by dividing exports of goods (or services) by GDP. The result is shown in figure 10.2. 


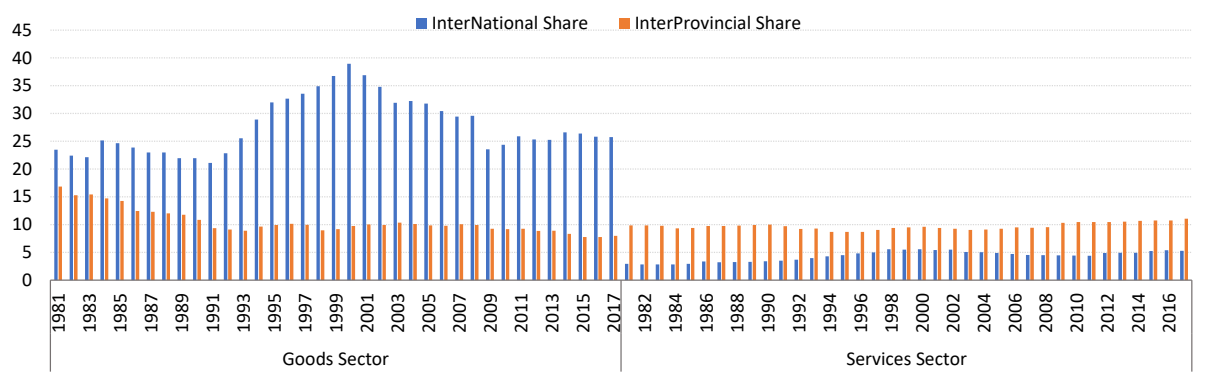

Figure 10.2: Share of international and interprovincial exports in GDP (showing the composition of goods vs services exports) - at the country level

Source: own elaboration (Based on Data from Statics Canada).

The indicators of international and interprovincial export shares differ for goods and services in many respects. While the relationship between the export shares in the two outlets (for goods sector) followed the same pattern as total export in figure 10.1, the trend reveals a completely different pattern for the services sector when compared to the same total export in figure 10.1. The analysis shows that over $80 \%$ of the Canadian merchandise export made its way to the foreign markets, indicating the high level of Canada's involvement and share in international trade in goods. In terms of services exports, the trend shows a continuous decline over the years for the international market but sluggishly stayed on the path of growth interprovincially.

\subsection{Evolution of exports by province}

For the provinces, we studied the evolution of exports using the 2005 pre-recession and 2017 annual data. A look at the frontiers of the aggregate relationship between interprovincial and international export shares reveals the two large central provinces of Ontario and Quebec as the major drivers. Export patterns in these two provinces followed a similar trend as the overall Canadian pattern. The international openness of both provinces decreased in 2017 when compared to 2005 pre-recession level. Atlantic provinces experienced similar trends in the evolution, apart from Prince Edward Island, where the share of the interprovincial exports stood above the international share in 2017, and more than 2005 levels. For all other Atlantic provinces, the share of international export decreased substantially compared to those of interprovincial export shares when compared to 2005 pre-recession levels. The four western provinces exhibit little similarity in the evolution of export links. The two Canadian provinces of British Columbia and Saskatchewan did not witness a substantial fall in the share of interprovincial exports throughout the period under emphasis. Manitoba's 
interprovincial export shares increased at the same rate as the 2005 pre-recession level in 2017 over the international share.

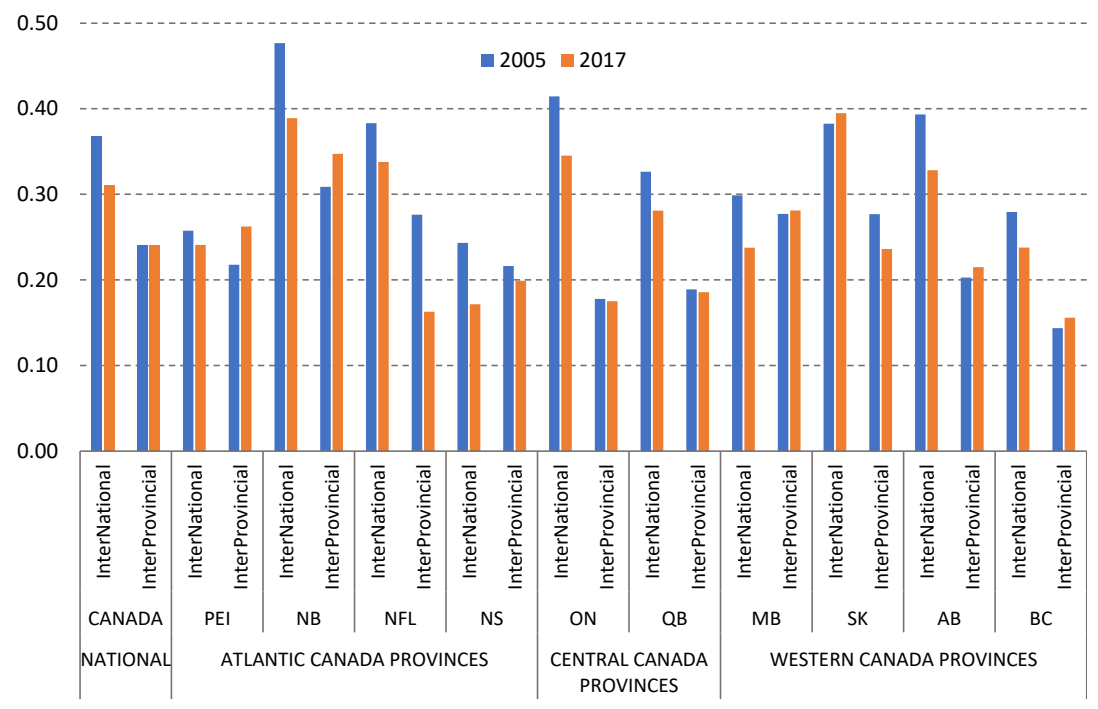

Figure 10.3: Share of provincial international and interprovincial exports in GDP, 2005 and 2017 Source: own elaboration (Based on Data from Statics Canada).

Canadian trade patterns and their drivers have transformed dramatically in response to the global economic environment. Canada's openness has continued to expand. The economy is yet to recover fully from the impact of the global financial crisis, coupled with the recent NAFTA renegotiation. The contents of the new terms are expected to have a huge impact on Canada, as approximately more than $75 \%$ of its export activity is destined for NAFTA partners - especially its southern neighbour, which also is the source of about one-third of foreign direct investment inflows.

\subsection{The provinces' exports dynamics and characteristics}

In this part, we mainly focus on international trade (exports of goods and services); export data is defined as the total business shipments (goods and services) from respective Canadian provinces to other countries. Statistics Canada and Industry Canada (Trade Data online) are the two main sources of our data on exports. For Canada, two main classifications of databases are available: (i) by products, (ii) by industry (economic activity). Both data classifications are relevant and were 
utilised in our study. Our export dynamics measures are captured by different ratios and indices, which includes percentage growth in exports, provincial share in total national export, trade openness (export to GDP ratio and export per capita), shares of sectoral products, export destinations, concentration ratios (HHI), the share of hightech products in total exports. However, one of the limitations encountered relates to data suppression for confidentiality reasons.

In this subsection, we identify the peculiarity in the export profiles of each of the ten Canadian provinces and three territories, by examining the differences in their dominant sectoral product exports and other respective export characteristics. For example, the product diversification levels of provinces and territories based on 2018 Customs data shows that the western coast of British Columbia is historically known for relying on natural resources such as mining and timber. However, the economy is now benefiting much more from manufacturing, and the province has also recorded tremendous growth from services. Alberta has gained so much from natural resources, including oil and natural gas. It also has an abundance of zinc, silver, nickel, and uranium.

On the other hand, the provinces of Manitoba and Saskatchewan supply over $20 \%$ of the world's wheat. These two provinces, including Alberta, also engage in some notable forms of farming that contribute to the national economy. Manitoba has also expanded tremendously in manufacturing in the recent period. Interestingly, today Canada is on record as the highest producer of potash in the world all because of the province of Saskatchewan.

Importantly, the central Canada provinces of Ontario and Quebec form the industrial hub of Canada. They are leaders in a variety of manufactured goods. Ontario is also widely known for its orchard and wine production. The Atlantic provinces of New Brunswick, Nova Scotia, Newfoundland, and Prince Edward Island have benefited immensely from fishing and natural resources such as timber, and potatoes in Prince Edward Island. PEI and Nova Scotia have gained more from services when compared to their counterparts in the Atlantic. Lastly, the three Canadian territories are purely driven by natural resources, such as minerals, precious metal and stones. The Northwest territory has continued to make a fortune from diamonds; the Yukon territory has advanced with copper, the territory of Nunavut has made progress with iron ores. The three territories also benefited immensely from gold. 


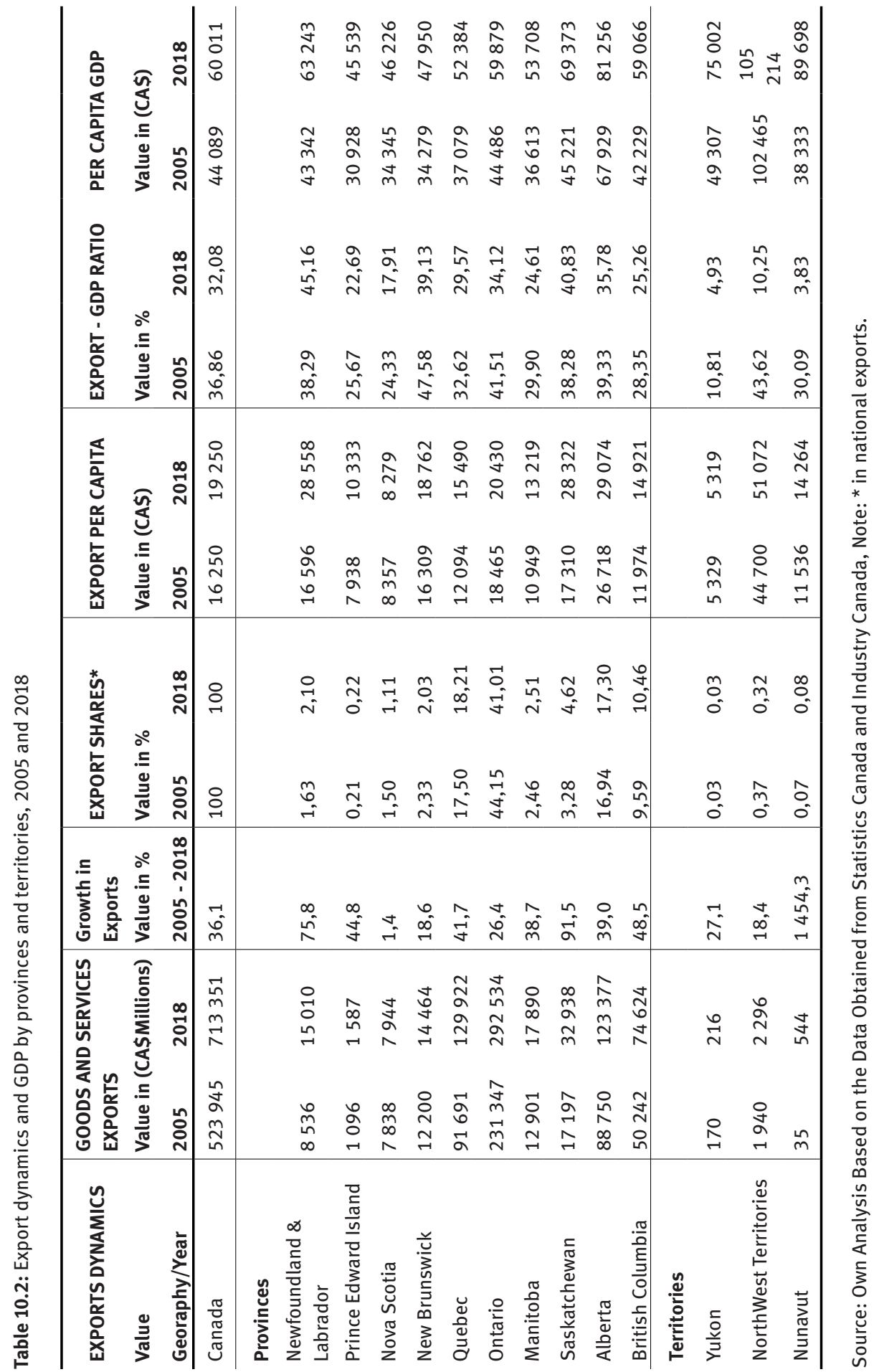




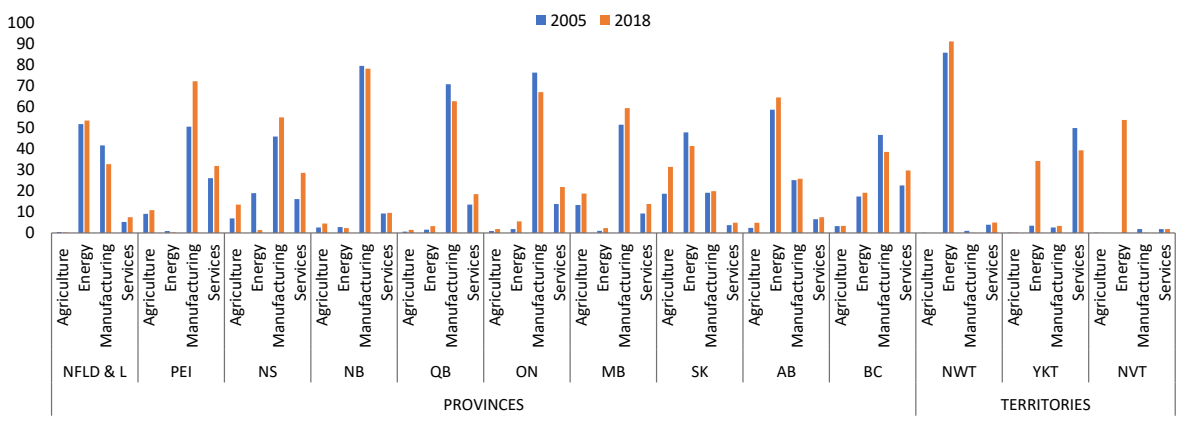

Figure 10.4: Percentage share of sectors in total provinces and territories' exports, 2005 and 2018 Source: own elaboration (Based on Data from Industry Canada-Trade Data Online).

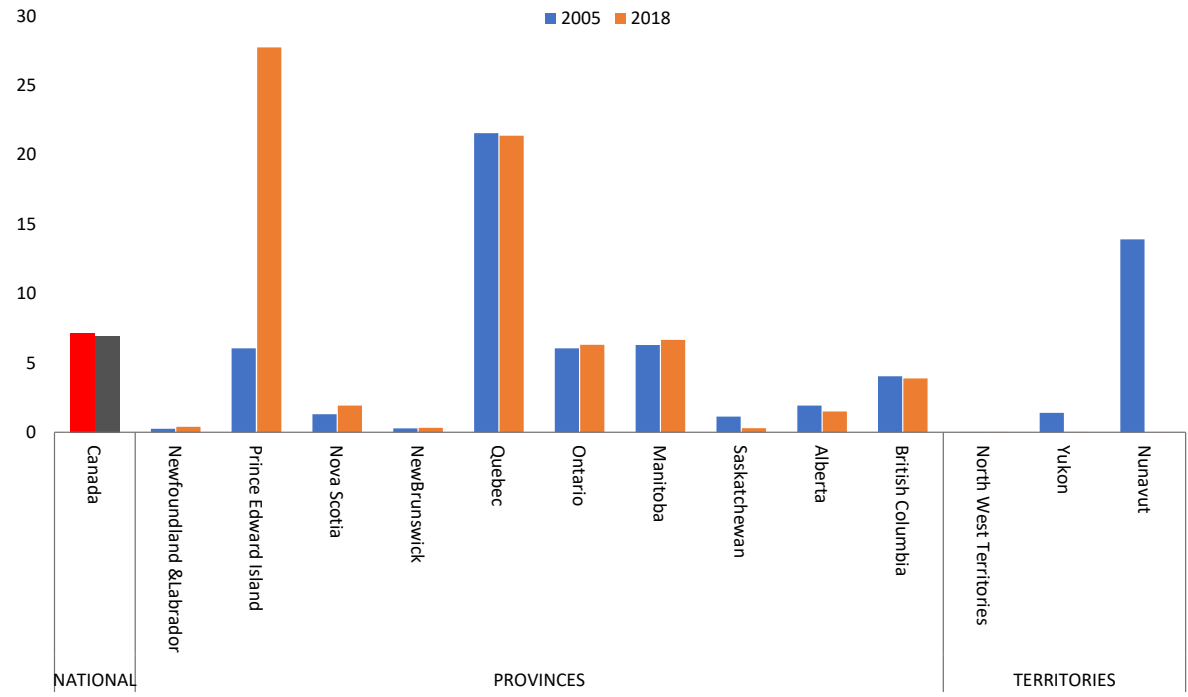

Figure 10.5: The percentage share of high-tech products in total provincial and territorial exports 2005 and 2018

Source: own elaboration (Based on Data from Industry Canada - Trade Data Online).

High-tech are products with a high intensity of expenditures on R\&D, such as in aerospace, computers, pharmaceuticals, scientific instruments, and electrical machinery. Performance in high-tech exports was led by provinces where the manufacturing sector is the key component of the total exports. Among all the Canadian provinces 
and territories, the strongest exports performance in high-tech stems from aircrafts and unwrought aluminium exports from Quebec; motor vehicles and unwrought gold exports from Ontario; pharmaceutical sales from Manitoba; and turbo propellers shipment from Prince Edward Island. They constitute the leading provinces in the Canadian manufacturing exports and, by extension, the shipment of high-tech products to the global markets. The metropolitan provinces of Quebec and Ontario stand out more in high-tech shipment. Overall, the average value for Canada of high-tech exports as a percentage of total manufactured exports was $15.6 \%$ in 2018.

Table 10.3 outlines the share in percentages of exports directed to top destinations and the rest of the world. Among the top export destinations are the US, the EU, China, Japan, India, South Korea, Mexico and the rest of the world (Rest W). The LQ index was calculated as the ratio of exports (directed to particular destination) to the total province or territorial exports divided by the ratio of total exports shipment to a particular destination, at the national level.

The US is a very important destination for all the Canadian provinces and the territory of Yukon (the outlier 94.57\%) among all the provinces and territories. The huge share evidence recorded in the US market reflects the importance of adjacency, the role of trade policy (especially the NAFTA), and other key forces within the framework of the gravity. All the provinces recorded export share of more than $1 \%$ from China, EU and Rest of $\mathrm{W}$ - which has shown substantial differences among the provinces and territories. The territories of Northwest and Nunavut are the main exporter for Canada to both the European Arctic States and rest of the world. While the mineral export of Alberta and Yukon went to the US, those of the Northwest and Nunavut territories headed to the European Arctic States and rest of the world in 2018.

The LQ accounts for the differences in relative intensity of trade links attributed to each of the provinces and territories in geographical terms. The index revealed substantial comparative advantage for the provinces in many markets. For example, British Columbia was found comparably better in South Korea, Japan, India, China and other parts of the world. Saskatchewan also gained an advantage in China, India, Mexico, Japan and the rest of the world. Among all the provinces and territories, Newfoundland and Labrador, Nunavut and Northwest territory are comparatively strong in the EU markets. Interestingly, no strong comparative advantage was revealed for all the provinces and territories in the US market - only New Brunswick, Alberta, and Ontario showed a weak advantage with the key partner of Canadian trade.

Concentration index was derived using the HHI. ${ }^{24}$ It has been utilised in this work as an inverse measure of export diversification. Export diversification refers to the

24 The three categories and thresholds jointly approved in 2010 by the Federal Trade Commission and the US Department of Justice are as follows: Diversified (unconcentrated) exports or markets: $\mathrm{HHI}<0.15$, Moderately concentrated Exports or markets: $0.15 \leq \mathrm{HHI}<0.25$, and Highly concentrated exports or markets: $\mathrm{HHI} \geq 0.25$. 
extent to which provincial and territorial export base is broad, in terms of products, trading partner countries or provinces of production..$^{25}$ For the sake of interpretation of the HHI, this paper followed the Horizontal Merger Guidelines jointly approved in 2010 by the Federal Trade Commission and the US Department of Justice, to differentiate between levels of diversified and concentrated exports or markets.

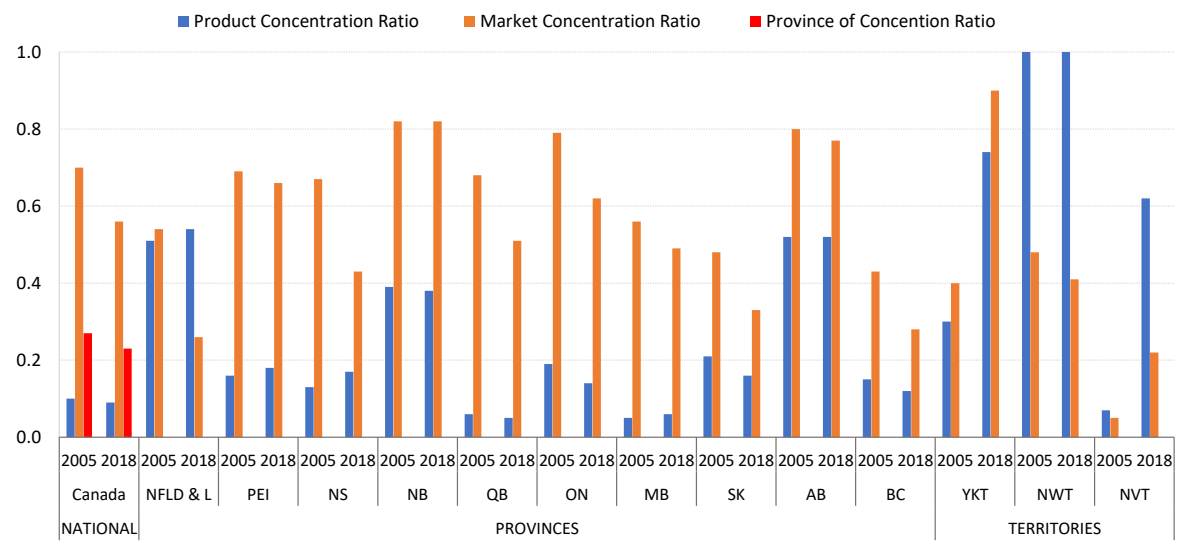

Figure 10.6: $\mathrm{HHI}$ of product and market concentration in provinces' exports

Source: own elaboration (Based on Data from Statistics Canada).

Canada has a highly concentrated destination market, with the majority of its exports going to its neighbour and principal trading partner, the US. Provincially, Ontario's exports were deemed moderately diversified product-wise, but highly concentrated marketwise, mainly due to motor vehicles and parts (representing on average $21 \%$ of Ontario's exports in 2018). With a concentration ratio of less than 0.15, Quebec, Manitoba, and British Columbia had a diversified basket of export goods, at the considered level of product aggregation. Product export from Saskatchewan, Nova Scotia, and Prince Edward Island was moderately concentrated since the concentration ratio was such that $0.15 \leq \mathrm{HHI}<0.25$. Exports from Newfoundland and Labrador and New Brunswick, including all the three territories were deemed highly concentrated, as given by a Herfindahl-Hirschman index greater than 0.25 in the period. All the provinces and territories apart from Nunavut were considered highly concentrated geographically. While the province and other territories reached HHI greater than 0.25 , Nunavut was deemed moderately concentrated given that the territory maintained an $\mathrm{HHI}$ of $<0.25$.

25 Data on province of production at the provincial level is supressed for confidentiality reasons, the concentration index for province of production is only available at the country level: https://www150. statcan.gc.ca/t1/tbl1/en/tv.action?pid=1210012901 


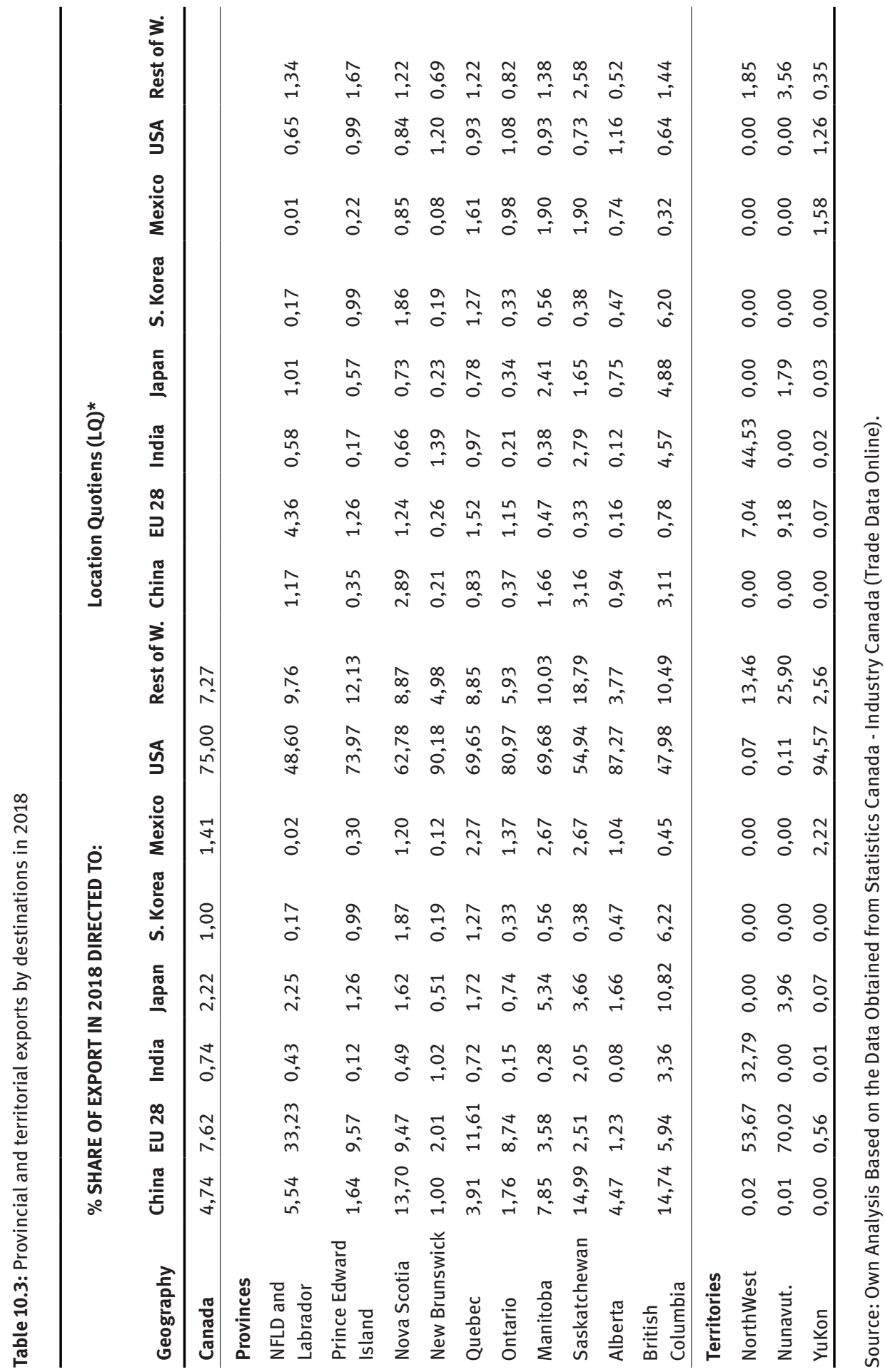


Generally, Canada, through the provinces and territories, has continued to show strong performance in trade. However, the country is still facing a relatively less diversified export market, with about $75 \%$ of foreign sales destined for the US alone. As can be expected, the obtained $\mathrm{HHI}$ calculations were in line with expectations, showing a high correlation with the US share in exports.

Although, in recent years, Canadian exporters have enjoyed remarkable success in penetrating other international markets, with much of the additional growth coming from shipments to Asia and Europe. Sales to China have increased, as have exports to the UK, and a number of other countries in recent years. Overall, the US is far more important to Canada than any other destinations, and the reflections are all over the entire Canadian provinces and territories, though the story is different for Newfoundland and British Columbia, which seemed to be more geographically diversified, as well as the territories of Northwest and Nunavut, which are geographically concentrated to the EU market. There is not much evidence pointing to the impact of NAFTA for many of the provinces and territories in terms of trade relationship with Mexico.

\subsection{Trade openness and provinces' prosperity}

As mentioned earlier, all the Canadian provinces and territories have relied on export revenues as a contributor to their economic growth, and many studies have been carried out to unravel the nature of the relationship. Interestingly, many authors in the past have studied the relationship between trade openness and economic growth - particularly exports, since it constitutes a large component of aggregate demand, such that an increase in exports leads to an increase in aggregate demand and results in higher economic growth (Frankel and Romer (1996) expanded on the similar issue). As expected, Zestos and Tao (2002) found a causal relationship between trade and economic growth for Canada and the US.

In our case, we extend the analysis to Canadian provinces and territories by examining the correlation between export per capita and per capita GDP. Export per capita is defined as the ratio of total exports to the province's population, and per capita GDP is defined as the ratio of the province's income level to their respective population. In our analysis, we provided insight regarding the specific directions of the GDP per capita in response to changes in the values of the export variable, for the period of 2010-2018. To further strengthen the results from our correlation coefficients, we have also analysed how well trade openness explains or predicts the future prosperity of the provinces and territories, by considering the coefficient of determination $\left(\mathrm{R}^{2}\right)$ measures. An $\mathrm{R}^{2}$ of $50 \%$ and above denotes a strong explanatory power, while an $\mathrm{R}^{2}$ of less than $50 \%$ denotes weak explanatory power. 
Table 10.4: Correlations of provincial and territorial export per capita and GDP per capita, 2010 -2018

\begin{tabular}{|c|c|c|c|c|c|c|c|c|c|c|c|c|c|c|c|}
\hline PROVINCES & $\begin{array}{c}\text { S/TERRITORIES } \\
\text { VARIABLE }\end{array}$ & $\begin{array}{l}\text { Canada } \\
\text { EXP. Per } \\
\text { Cap. }\end{array}$ & $\begin{array}{l}\text { NFLD\&L } \\
\text { EXP. Per } \\
\text { Cap. }\end{array}$ & \begin{tabular}{l}
\multicolumn{1}{c}{ PEI } \\
EXP. Per \\
Cap.
\end{tabular} & \begin{tabular}{l}
\multicolumn{1}{c}{ NS } \\
EXP. Per \\
Cap.
\end{tabular} & \begin{tabular}{l}
\multicolumn{1}{c}{$\mathbf{N B}$} \\
EXP. Per \\
Cap. \\
\end{tabular} & \begin{tabular}{l}
\multicolumn{1}{c}{ QB } \\
EXP. Per \\
Cap.
\end{tabular} & \begin{tabular}{l}
\multicolumn{1}{c}{ ON } \\
EXP. Per \\
Cap.
\end{tabular} & \begin{tabular}{l}
\multicolumn{1}{c}{ MB } \\
EXP. Per \\
Cap.
\end{tabular} & \begin{tabular}{l}
\multicolumn{1}{c}{ SK } \\
EXP. Per \\
Cap.
\end{tabular} & \begin{tabular}{l}
\multicolumn{1}{c}{$\mathbf{A B}$} \\
EXP. Per \\
Cap.
\end{tabular} & \begin{tabular}{l}
\multicolumn{1}{c}{ BC } \\
EXP. Per \\
Cap.
\end{tabular} & \begin{tabular}{l}
\multicolumn{1}{c}{ YKT } \\
EXP. Per \\
Cap.
\end{tabular} & $\begin{array}{l}\text { NWT } \\
\text { EXP. Per } \\
\text { Cap. }\end{array}$ & \begin{tabular}{l}
\multicolumn{1}{c}{ NVT } \\
EXP. Per \\
Cap. \\
\end{tabular} \\
\hline Canada & GDP Per Cap. & $\begin{array}{r}0,98901 \\
\mathbf{R}^{2}=0.99\end{array}$ & & & & & & & & & & & & & \\
\hline NFLD\&L & GDP Per Cap. & & $\begin{array}{l}0,72414 \\
\mathrm{R}^{2}=0.85\end{array}$ & & & & & & & & & & & & \\
\hline PEI & GDP Per Cap. & & & $\begin{array}{l}0,93914 \\
\mathrm{R}^{2}=0.97\end{array}$ & & & & & & & & & & & \\
\hline NS & GDP Per Cap. & & & & $\begin{array}{l}0,64068 \\
\mathrm{R}^{2}=0.80\end{array}$ & & & & & & & & & & \\
\hline NB & GDP Per Cap. & & & & & $\begin{array}{c}-0,2106 \\
\mathrm{R}^{2}=0.45\end{array}$ & & & & & & & & & \\
\hline QB & GDP Per Cap. & & & & & & $\begin{array}{l}0,98379 \\
\mathrm{R}^{2}=0.99\end{array}$ & & & & & & & & \\
\hline ON & GDP Per Cap. & & & & & & & $\begin{array}{l}0,95514 \\
\mathrm{R}^{2}=0.98\end{array}$ & & & & & & & \\
\hline MB & GDP Per Cap. & & & & & & & & $\begin{array}{r}0,82865 \\
\mathrm{R}^{2}=0.91\end{array}$ & & & & & & \\
\hline sk & GDP Per Cap. & & & & & & & & & $\begin{array}{c}0,76653 \\
\mathrm{R}^{2}=0.88\end{array}$ & & & & & \\
\hline AB & GDP Per Cap. & & & & & & & & & & $\begin{array}{l}0,95603 \\
\mathrm{R}^{2}=0.98\end{array}$ & & & & \\
\hline BC & GDP Per Cap. & & & & & & & & & & & $\begin{array}{c}0,9944 \\
\mathrm{R}^{2}=0.99\end{array}$ & & & \\
\hline YKT & GDP Per Cap. & & & & & & & & & & & & $\begin{array}{c}-0,3383 \\
\mathrm{R}^{2}=0.58\end{array}$ & & \\
\hline NWT & GDP Per Cap. & & & & & & & & & & & & & $\begin{array}{c}0,689 \\
\mathrm{R}^{2}=0.83\end{array}$ & \\
\hline NVT & GDP Per Cap. & & & & & & & & & & & & & & $\begin{array}{l}0,95431 \\
\mathrm{R}^{2}=0.98\end{array}$ \\
\hline
\end{tabular}

Trade openness (international export) increases and correlates positively with the economic prosperity of most of the provinces and territories, apart from New Brunswick and Yukon, where the relationship is negative. Thus, strong results at the country level and from most of the provinces and territories combined, show that provincial openness to trade (in particular, international export) correlates with the provincial prosperity (proxied by per capita GDP). It is supported by a high coefficient of determinations at the country level and for many of the provinces and territories.

\subsection{Provincial openness to trade and the labour market fundamentals}

The relationship between trade liberalisation and the labour market situation has generated a lot of controversy among researchers. For example, in the 1980s, there was an extensive deliberation regarding the effects of CUSFTA. During this period, there were widespread fears, especially those harboured by the labour unions and those opposed to the idea of external agreements, that trade liberalisation with the US would adversely impact wages and employment of workers in domestic industries. In fact, the 1990-1992 recession was perceived by some trade analysts (opposed to free trade) as evidence of the negative influence of trade on the labour market. Some studies likewise have measured the impact of the reduction in industry-related tariffs on wages and employment. A close example is Gaston and Trefler (1997), who aggregated establishment data, and provided some evidence of the negative impact of 


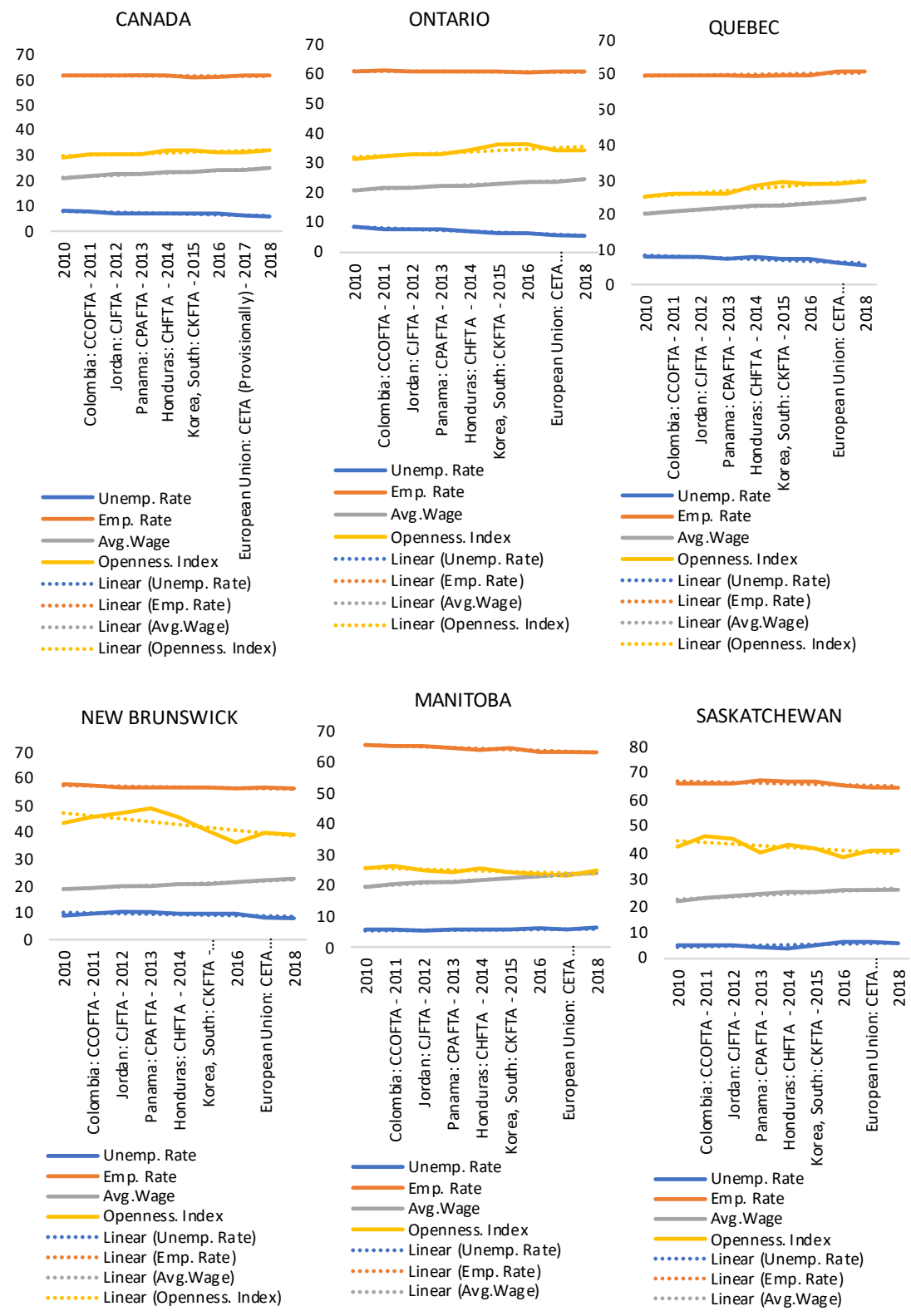

Figure 10.7: Provincial trade openness and key labour market indicators Source: own elaboration. 
NFLD \& LABRADOR

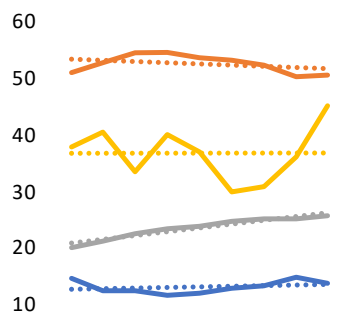

0

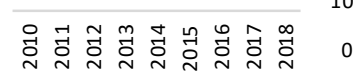
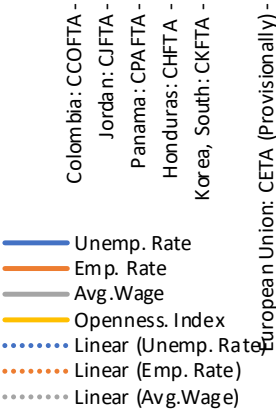

NOVA SCOTIA
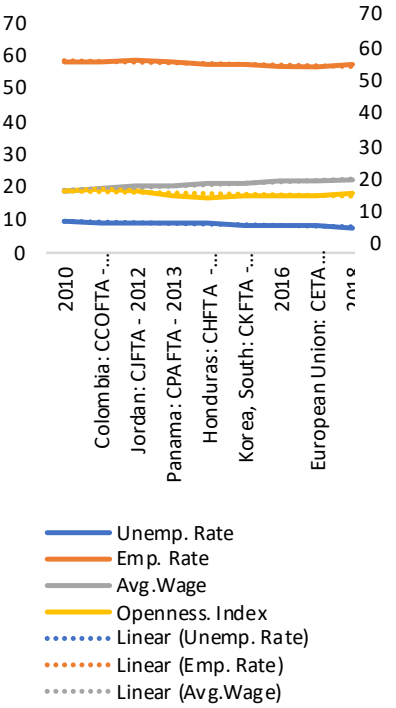

YUKON TERRITORY
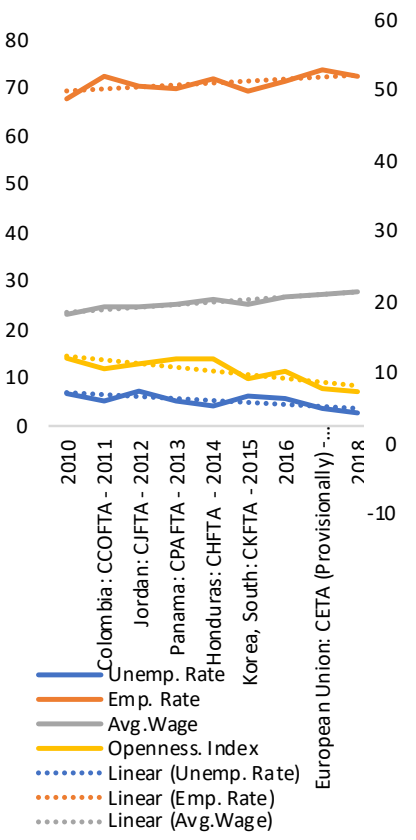

$-10$

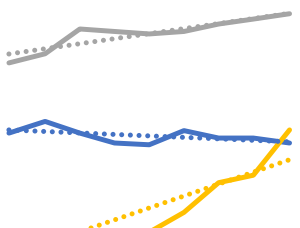

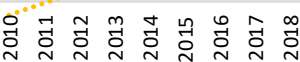

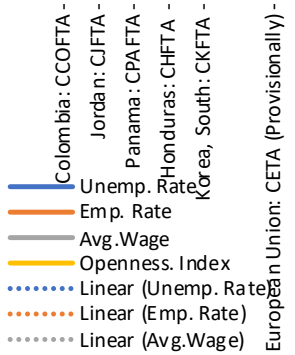

BRITISH COLUMBIA
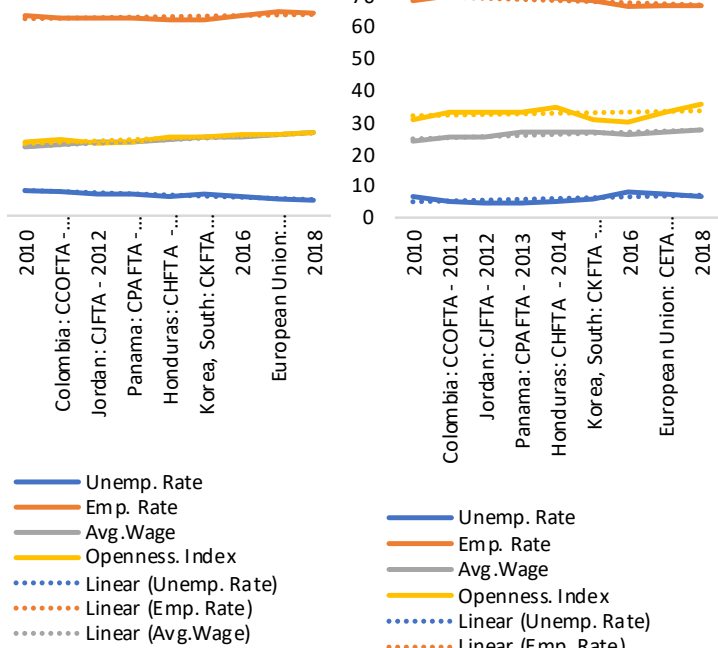

Figure 10.7: Provincial trade openness and key labour market indicators

Source: own elaboration. 


\section{PRINCE EDWARD ISLAND}

70
60
50
40
30
20
10
0
NORTHWEST TERRITORY

80

70

60

50

40

30

20

10

0

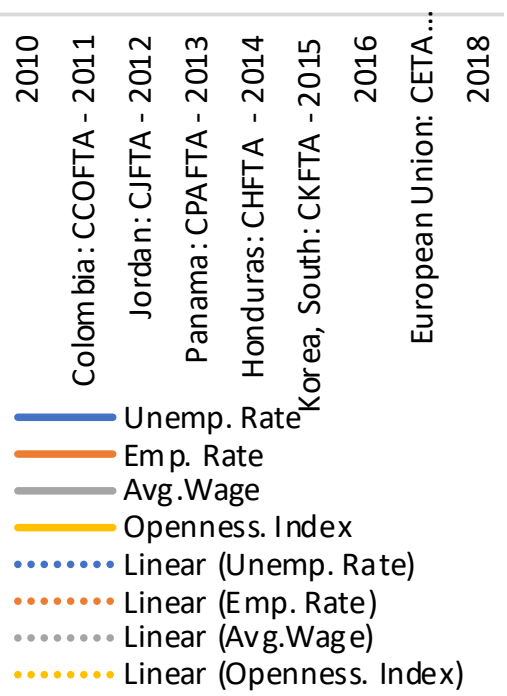

Figure 10.7: Provincial trade openness and key labour market indicators Source: own elaboration. 
tariffs' reductions on employment, but found minimal of such effect on wages (further proof of sticky downward wage theory), this is also in line with the findings of Beaulieu (2000). However, through the application of household data (with the leverage to control for individual workers' characteristics such as gender, education experience etc.), Townsend (2007) revealed some significant negative influence of tariffs reduction on wages. As the actual relationship remains uncertain and the debate keeps on stretching, the labour market consequences of trade openness are analysed in this section for the Canadian sub-regions. Specifically, we provide insights on the relationship by interacting provincial and territorial employment rates, unemployment rates, average hourly wage and the index of provincial trade openness.

The sample period 2010 to 2018 reveals wage and employment growth were spread across many of the provinces, with a corresponding fall in the rate of unemployment in many of the provinces and territories. The unemployment rate increased only in the province of Manitoba (5.4 to 6.0), and the Northwest territory (6.6 to 7.3). Other provinces and territories saw a reduction in the rate of unemployment viz: QB (6.1 to 5.5), ON (6.0 to 5.6), NFLD\&L (14.8 to 13.8), PEI (9.8 to 9.4) NS (8.4 to 7.5), NB (8.1 to 8.0 ), SK (6.3 to 6.1), and (7.8 to 6.6), BC (5.1 to 4.7), YKT (3.6 to 2.7) and NVT (14.6 to 14.1). In $\mathrm{BC}, \mathrm{QB}, \mathrm{ON}$, and YKT unemployment rate decreased below the national average (5.8). The sample period showed expansion of many of the provinces in trade openness. The expansion in openness seems to have worked to bring down the level of unemployment in these provinces and territories. Average hourly wages also rose in many of the provinces and territories, but not at the same pace with openness expansion, except in BC and PEI where they both grew at the same rate and $\mathrm{MB}$ where they both increased at similar pace towards the end of the sample period. Although the result is not the same for Nova Scotia, Yukon and Nunavut, where openness to trade is still lower than would be expected to take into consideration their respective average hourly wage levels. Nunavut is a special case with trade openness that seems to have staggered below unemployment and average wage levels until 2018 when openness rose to tame the unemployment level. Still, the average wage remained high, waiting to be fully utilised. A closer look at figure 10.7 confirms the Central Canada provinces of ON and QB as the key drivers of the changes (in the labour market) we noticed at the national level.

\subsection{Conclusions}

Our contribution is mainly on the characteristics of Canadian international trade (exports) by provinces and territories. In doing so, we first looked at the comparative evolution of the Canadian trade patterns both at the country and provincial levels, in order to identify changes in export structure. We showed how trade at the national level has diverted towards the international frontier in response to adjacency and changes in external relations, while the interprovincial outlet has remained constant 
over time. More importantly, we analysed the export dynamics of the Canadian provinces and territories, reflecting the heterogeneity of their export profiles. In Canada, we do not make the economic comparison between the provinces and the territories, the territories are scarcely populated, and cannot compare with the provinces in terms of economic engagements, the activities of Canadian territories do not impact much on the overall Country level.

Canada, being the world second-largest country in terms of geography, has a population of over 37 million people, with more than half of the number concentrated in the central provinces of Ontario and Quebec, the two largest metropolitan provinces in Canada. As the $10^{\text {th }}$ in the global ranking of the world largest economies, Canada is blessed - being geo-positioned close to the world's largest economy - the US. Thus, our analysis at country level reveals a remarkable shift in the evolution of trade patterns, which seem to have favoured international trade over interprovincial trade as a result of the interplays of some key gravity forces. A closer look at the recent years (pre-recession 2005 and post-recession 2018) produced similar results for most of the provinces and territories, who also are not immune from border effects and are inevitably controlled by the whims and caprices of national trade policies. Overall, while Canadian exports were found to be diversified by product and were discovered to be concentrated by the geographic market - hugely to its southern neighbour (US). It is the propelling the idea behind Canada's goal of increasing overseas exports by over $50 \%$ if possible, by 2025.

Provincially, we analysed dynamics in exports, which identified the peculiarity of individual provinces and territories in terms of export product-mix and their respective level of international engagement and export performance. The range of goods and services exported by Canadian provinces are wide, with sufficient distribution among commodity groupings that are considered diversified in the portfolio of Canadian exports. The largest sectors are manufacturing and energy. Agriculture and services have also performed remarkably in some of the provinces. All Canadian provinces and territories have relied on export revenues as their source of growth. With high export concentration, provincial export earnings may suffer from commodity price fluctuations driven by unexpected changes in the global economic environment and subsequently lead to significant trade shocks. As a result, Canada has continued to engage in policy negotiations that will aid the increase of overseas exports. Although some experts have considered the FTA with Canada's second-largest trading partner. The conclusion of the Canada-EU FTA beyond the provisional level will be a good step in the right direction to increase export.

Concerning the state of the labour market, one visible experience is that the Canadian labour market has continued to stay resilient in recent years, despite the challenges posed by the global economic environment. For all the Canadian provinces, the emerging signals across key labour market indicators point to a tightening of the labour market, with several of the indicators showing positive trends for the provinces in the most recent years, which includes total employment growth and a 
decreasing trend in the provincial unemployment rate. Also, the average earnings saw a notable increase in all the provinces. All of these performances came in the same period with stronger economic growth in many of the provinces.

Some of the provinces and territories are driven by natural resource abundance. Thus, export exposure can result in DD or the so-called resource curse, which are susceptible to an increase in mining, and oil and gas exports. Our analysis that tended to expose this phenomenon was carried out at the provincial and territorial levels. In our efforts, we tried to answer the question of whether there is a correlation between the degree of international export exposure and the provinces' prosperity. Our findings answered the above question in an affirmative way and conceded to the fact that increased openness to international exports enhances the provinces' prosperity. Evidence from the resourced based provinces of Albert, Saskatchewan, and Newfoundland and Labrador, as well as Northwest territory, are a good case in point. 
